\title{
Cutis verticis gyrata in a paediatric patient with cochlear implants
}

\author{
Neeti Patel (1) , ${ }^{1}$ Fiona McClenaghan, ${ }^{2}$ Sevasti Konstantinidou, ${ }^{3}$ Robert Nash ${ }^{3,4}$
}

${ }^{1}$ NHS Trust Ear, Nose and Throat Surgery Department, Great Ormond Street Hospital for Children, London, UK

${ }^{2}$ Great Ormond Street Hospital For Children NHS Trust, London, UK

${ }^{3}$ Ear, Nose and Throat Surgery Department, Great Ormond Street Hospital For Children NHS Trust, London, UK

${ }^{4} \mathrm{UCL}$, London, UK

\section{Correspondence to}

Neeti Patel;

neeti.patel@gosh.nhs.uk

Accepted 11 June 2021
Check for updates

(C) BMJ Publishing Group Limited 2021. No commercial re-use. See rights and permissions. Published by BMJ.

\footnotetext{
To cite: Patel $\mathrm{N}_{t}$

McClenaghan $F_{\text {, }}$

Konstantinidou S, et al. BMJ Case Rep 2021;14:e244150. doi:10.1136/bcr-2021-

244150
}

\section{DESCRIPTION}

Cutis verticis gyrata (CVG) is a rare congenital or acquired scalp condition characterised by convoluted folds and deep furrows that resemble the surface of the cerebral cortex. ${ }^{1}$ It occurs more commonly in males and most commonly develops after puberty, but before age $30 .^{2}$ It may occur as primary essential, primary non-essential or secondary CVG. Primary nonessential CVG is often in association with neuropsychiatric or ophthalmological abnormalities, and secondary CVG is associated with a number of localised or systemic inflammatory processes such as, eczema, psoriasis, folliculitis and impetigo or other pathologies including hamartomas or naevi. Primary essential CVG has no associations. ${ }^{12}$ The pathogenesis of primary CVG remains unclear. ${ }^{3}$ A hormonal influence has been postulated as this disorder usually manifests in postpubertal men. ${ }^{3}$ Secondary CVG is considered to be a manifestation of a variety of underlying causes, and the pathophysiology, in this case, can be correlated to the specific underlying condition. ${ }^{3}$ The estimated prevalence rate of CVG in an adult population is 1 in 100000 in men and 0.026 in 100000 in women. ${ }^{3}$ CVG rarely presents in young children. ${ }^{3}$ A higher prevalence is reported in patients with intellectual disability. ${ }^{3}$ Usually it is a clinical diagnosis, although multiple investigations, such as skin biopsies, bloods tests and radiological examinations can be done to distinguish between primary and secondary forms of CVG. ${ }^{3}$

Cochlear implants are surgically implanted prosthetic devices that electrically stimulate the cochlear nerve to provide hearing. ${ }^{4}$ The device consists of a battery-powered external processor (that looks like a hearing aid), and an internal stimulator-receiver package implanted below the scalp with an electrode inserted directly into the cochlea through a surgical opening. ${ }^{4}$ The internal and external components communicate via antennae that are held close to one another using magnets. Hearing impaired patients who require cochlear implants have lifelong follow-up to aid rehabilitation, monitor for potential complications, and to facilitate care if complications occur. The most common complications usually seen are vestibular complications, (eg, dizziness, balance problems), device failure, infections and inflammatory conditions such as mastoiditis, skin infections, cholesteatoma, seroma and recurrent otitis media. ${ }^{5}$

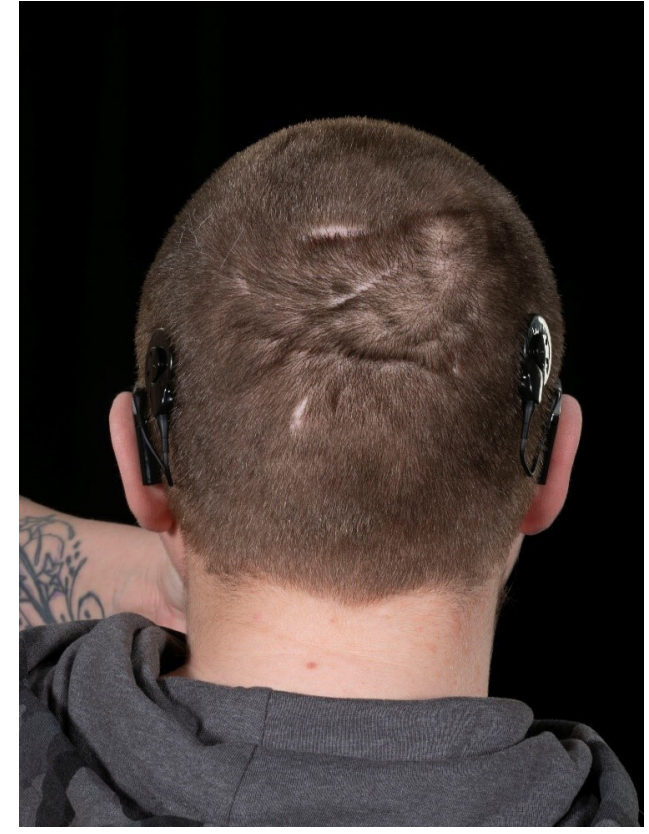

Figure 1 The clinical image shows convoluted folds and deep furrows on the back of the patient's head, which is consistent with cutis verticis gyrata.

In this case, a 14-year-old man presented with deep rippling and tenderness of the scalp underlying the implant package (figure 1). He had a medical history of sensorineural hearing loss bilaterally, diffuse otitis externa, cataract in the right eye, leading to right sided blindness and developmental delay. He had unilateral cochlear implant insertion at 2.5 years of age-and then sequential insertion at 7.5 years of age. On physical examination, the deep ripples first presented 5 months ago and were soft to palpation with no overlying skin changes or tenderness. The presentation is indicative of CVG. The patient was managed by increasing the strength of the external magnet to improve fixation of the coil.

Learning points

Cutis verticis gyrata (CVG) in children is rare.

- If presented in a patient with cochlear implants, this can cause a problem with compliance, therefore, requiring adjusting the strength of the magnet.

- CVG can be a potential complication of Cochlear implantation, due to local irritation or trauma to the scalp. 
CVG can be a potential complicating factor in cochlear implantation as rippling of the skin increases the distance between the internal and external magnets, reducing their attraction and making the processor coil susceptible to falling off frequently. Depending on the severity, this can significantly reduce or even completely prevent use of the implant.

CVG, aside from altered cosmeses, has no significant complications. ${ }^{3}$ The treatment is supportive in terms of scalp hygiene to avoid accumulation of secretions in the furrows. ${ }^{3}$ This article highlights CVG as a potential complication of cochlear implantation.

Contributors NP can confirm that all the authors have read and contributed adequately to the final manuscript submitted for publication. NP contributed in the gathering of information, writing and editing the paper. FM contributed in the management of the patient and editing the paper. SK contributed in writing and editing the paper. RN contributed in management of the patient and overviewing the final manuscript.

Funding The authors have not declared a specific grant for this research from any funding agency in the public, commercial or not-for-profit sectors.
Competing interests None declared.

Patient consent for publication Parental/Guardian consent obtained.

Provenance and peer review Not commissioned; externally peer reviewed.

\section{ORCID iD}

Neeti Patel http://orcid.org/0000-0003-3481-7652

\section{REFERENCES}

1 Larson F. Cutis Veriticis gyrata, 2018. Available: https://www.uptodate.com/ contents/cutis-verticis-gyrata?search=cutis $\% 20$ gyrata\%20verticis\&source=search result\&selectedTitle $=1 \sim 2 \&$ usage_type $=$ default\&display_rank=1 [Accessed 3 Mar 2021]

2 Skibinska MD. Cutis verticis gyrata. Medscape reference, 2016. Available: http:// emedicine.medscape.com/article/1113735-overview

3 Shareef S, Horowitz D, Kaliyadan F. Cutis verticis gyrata, 2020. Available: https://www. ncbi.nlm.nih.gov/books/NBK539812/ [Accessed 25 Feb 2021].

4 Smith R. Hearing loss in children: treatment, 2021. Available: https://www.uptodate. com/contents/hearing-loss-in-children-treatment? search=cochlear\%20implantation $\%$ 20in\%20peds\&source=search_result\&selectedTitle=2 94\&usage_type=default\& display_rank=2 [Accessed 21 May 2021].

5 Terry B, Kelt RE, Jeyakumar A. Delayed complications after cochlear implantation. JAMA Otolaryngol Head Neck Surg 2015;141:1012.

Copyright 2021 BMJ Publishing Group. All rights reserved. For permission to reuse any of this content visit https://www.bmi.com/company/products-services/rights-and-licensing/permissions/

BMJ Case Report Fellows may re-use this article for personal use and teaching without any further permission.

Become a Fellow of BMJ Case Reports today and you can:

- Submit as many cases as you like

Enjoy fast sympathetic peer review and rapid publication of accepted articles

- Access all the published articles

Re-use any of the published material for personal use and teaching without further permission

\section{Customer Service}

If you have any further queries about your subscription, please contact our customer services team on +44 (0) 2071111105 or via email at support@bmj.com.

Visit casereports.bmj.com for more articles like this and to become a Fellow 